\title{
The Profitability of Banking Sector in Republic of Macedonia
}

\author{
Meri Boshkoska ${ }^{1}$ \\ ${ }^{1}$ Faculty of administration and management of information systems in Bitola, Republic of Macedonia \\ Correspondence: Meri Boshkoska, Faculty of administration and management of information systems in Bitola, \\ Republic of Macedonia. E-mail: meribb@yahoo.com
}

Received: December 7, 2012

Accepted: January 22, 2013

Online Published: February 22, 2013

doi:10.5539/ijef.v5n3p143

URL: http://dx.doi.org/10.5539/ijef.v5n3p143

\begin{abstract}
The banking sector has a dominant role in the process of mediating and dispersing the finances of the economical subject with suffice towards the ones with a deficit. Although it is well known fact that the banking sector plays the major role in the enhancing and developing of a country's economy, it is evident that this sector is under big influence of the changes within the financial environment-regarding the situation of the capital market on a global scale. If the banking sector functions efficiently, give loans to support the enterprises, it leads to bigger consumption-meaning that for the population of the country the banking sector is highly valued and trusted.
\end{abstract}

The paper examines the structure and the profitability of the banking sector in Republic of Macedonia comparing with the banking sectors of some countries in the region.

Keywords: bank's profitability, ROA, ROE, net-interest margin, non-performing loans, Basel III Accord

\section{Introduction}

It is essential for a country to have well structured and profitable banking sector in order to have more competitive and successful banking sector. For the existence of this kind of sector of particular importance is the range of profit that is realized by the banks. The stability of the financial system depends on the profitability of the banking sector. General problem of the banking sector in the Republic of Macedonia is the downward trend of its profitability in the past few years.

The main objective of this paper is to answer the following questions:

- Who are the most important reasons for the negative trend in the Macedonian banking sector's profitability?

- What needs to be changed in this sector to improve this situation?

Further down in this paper, through comparative analysis (with the banking sectors of other countries in the region) and research of its profitability, we will show the real situation in which at this point is the Macedonian banking sector.

The basic hypothesis that is tested in the paper is: If the structure of the banking sector in Republic of Macedonia is consolidates, then the trend of banks' profitability will be positive.To prove the hypothesis we used methods that will be based on:

- Content analysis of various domestic and foreign banking system reports, banking system indicators, publications and Financial statements of the National Bank of the Republic of Macedonia (NBRM).

- Comparative analysis.

The research paper is structured as follows. At the beginning, before we give the analysis of its profitability, it is crucial to present the structure and competition of the Macedonian banking sector in order to draw a conclusion whether are needed changes in the bank's structure.

The scope of the research is covering explanation of the mentioned objective and will depend on the knowledge that already exists in the literature and is provided by different authors that made past research in this field as well as on the data and analysis of the financial statements that are provided by home and foreign financial institutions.

Popovska (2008) provide a complex analysis of the performance of the commercial banking sector. Her findings showed that the basic problems in the Macedonian banking sector are: inadequate competition, high concentration of bank capital in a small number of big banks and undeveloped structure of services for the clients. 
According to CEA (2005) the structure of the Macedonian banking sector is highly concentrated and results in a low competition in this sector.

Findings of Davcev and Hourvouliades (2009) showed that the most important determinants of bank profitability are: Return on total Assets, total loss on loans and operative expenses are significant only in the ROE profitability.

Croatian Banking Association (2009) examined the reasons for the decline in the profitability of banks in Croatia compared to other countries in the region. According to this analysis, there are two reasons for this declined: short-term (profit and stability of the banking system) and long-term (ability to attract additional capital). The general conclusion is that low bank profit means that the economy remains without one of the most important factors for its growth and development.

Madzova (2011) examined the opportunities and challenges of introducing of Basel III. She emphasized that their introduction will result in an increasing in the bank costs. These indicate that we can expect a reduction in the profitability of the Macedonian banking sector, but not a problem in their fulfillment.

The mentioned research and findings represent the basis of our research, which is a small contribution to the modest research that we have on this topic. The paper contributes to the existing literature by researching the performance of the banking sector of which depends the economic growth and development of a country's economy.

\section{The Structure of the Banking Sector in Republic of Macedonia}

In this part, we will discuss the data about the number of banks functioning on the territory of the Republic of Macedonia, and analysis is made whether the number of the banks means efficient functioning of the banking sector.

The banking sector of the Republic of Macedonia consists of 17 privately owned banks and 8 depositories and loan houses (savings houses). (Note 1) Although there are fully functional depositories and loan houses (saving houses), still the major role in the financial market is played by the banks. In 13 of these banks, major shareholders are the foreign owners.

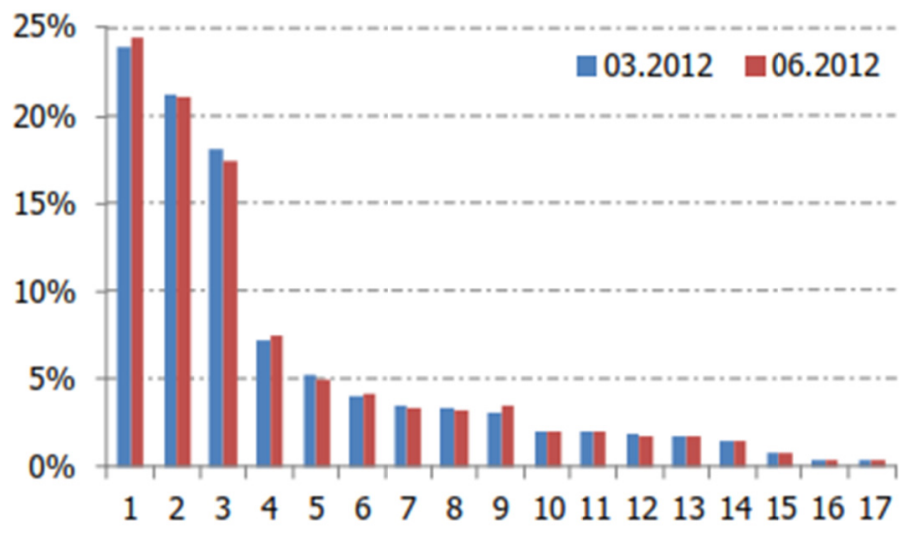

Figure 1. Share of each bank in the total assets of the banking system

Source: NBRM (2012). Report on Banking System of the Republic of Macedonia in the second quarter of 2012. Skopje, p. 9.

Most of the total assets of the banking sector are concentrated in the three largest banks which indicate the existence of a large concentration in the banking system. (Figure 1). This means that the Macedonian banking system is in a group of monopolistic competitive markets, with a relatively low level of competition.

The high concentration in the banking sector in Macedonia also means that there are banks, popularly called by the IMF and the WB "pocket banks"- meaning that these are smaller banks that are used as a cheap source of finance for certain groups and/or individuals in the country. Some of these smaller banks (banks with assets less than 6.200 million denars) (Note 2) realized small-scale activities, lower competition, and passive operation on the market. These banks should seek for a solution in finding strategic investors or in emerging with other banks. 
Having into consideration the critical point mentioned above about the banking sector in Republic of Macedonia we can offer a few suggestions that follow. Firstly, in order to stop the opening of new and operating of the existing small noncompetitive banks, that more than often are the reason why the total profit of the banking sector is getting lower, it is necessary to take several precaution measures. The most exceptional attention should be paid to establishing the conditions under which a permit for opening a bank is granted-meaning, increasing of the minimum requested ownership capital (which according to the latest Banking Law is increased from 3,5 to 5 million Euros) (NBRM, 2006) and the authority and the reputation of the person who intends to open a bank. Next, attention should be paid to the qualities and qualifications of the person who is meant to be the general manager-weather that person has the capacity for proper managing of the bank - to be closely controlled especially when it comes to giving loans with a high-risk factor-whether the loans are given to persons closely related to the managerial staff of the bank (so called connected crediting). Furthermore, it is necessary to have liable information on the legality of the capital that the person who wants to open a bank is giving as a deposit. Then, it is also important to establish a strict supervision according to the international standards, to publish on time the eventual measures for correction and enhancing of the functioning taken by the National Bank of Republic of Macedonia (NBRM) about the banks that encounter functional problems.

\section{Comparative Analysis of Macedonian Banking Sector Profitability}

\subsection{Macedonian Banking Sector - It's Profitability}

In order to compare the profitability of the Macedonian banking system, further in this text, first we will present information about the profits that the Macedonian banks makes (ranked according to how big they are) and we will make an analysis of the profitability with the banking sectors in some countries in the region.

The profitability of the banking system of a country is measured by the rate of return of assets (ROA), the rate of return of equity (ROE) and Net interest margin in order to better measurement the bank performances.

ROA indicates how well bank management used its total amount of assets (loans and investments) to earn income, or how much profit is created of each dollar in assets. (Center for Financial Training, 2010)

Although ROA provides useful information about bank profitability that is not what the bank owners care about most. They are more concerned about how much bank is earning on their equity investment that is measured by the return on equity -ROE. (Mishkin, 2012)

ROE shows how much the bank earned in comparison with the share holders' capital (Petkovski, 2009).

Investors can compare a bank's ROA and ROE to those of other banks to see how it performed relative to the other banks. A bank's ratios for several years can be reviewed to determine whether they have remained the same, increased, or decreased. A bank's ratios that decrease or stay the same are cause for concern. (Center for Financial Training, 2010)

A bank's net interest margin is the difference between the interest it receives on its securities and loans and the interest it pays on deposits and debt, divided by the total value of its earning assets. (Hubbard and O'Brien, 2012)

In table 1 are given standards for ROA and ROE indicators from lowest to highest. These standards will help us to determine on what level of this scale is the Macedonian banking sector.

Table 1. Standards for ROA and ROE

\begin{tabular}{ll}
\hline RATING ROA & RATING ROE \\
\hline Low - Bellow $0.5 \%$ & $15 \%$ - after taxation \\
Satisfying - $0.5 \%-1 \%$ & $25 \%$ - before taxation \\
Good - $1 \%-2 \%$ & \\
High - Above $2 \%$ & \\
\hline
\end{tabular}

Source: Popovska, K (2008). Commercial Banking - Success and profitability. Skopje,"Institute of economics”- Skopje, p. 167.

Qin.X and Pastory.D. (2012). Commercial Banks Profitability Position: The Case of Tanzania, p.137.

In the following text will be analyzed the trend of profitability observed by groups of banks and the entire banking sector in the country. The analysis is made by the following key indicators of the bank's profitability: ROAA, ROAE and Net interest rate/operational costs. 
Table 2. Rate of return of average assets (ROAA)

\begin{tabular}{llll}
\hline Group & $\mathbf{9 / 3 0 / 2 0 1 0}$ & $\mathbf{9 / 3 0 / 2 0 1 1}$ & $\mathbf{0 9 / 3 0 / 2 0 1 2 *}$ \\
\hline Large banks & $1.0 \%$ & $0.9 \%$ & $0.8 \%$ \\
Medium-size banks & $-0.5 \%$ & $-1.7 \%$ & $0.2 \%$ \\
Small-size banks & $-2.4 \%$ & $-2.8 \%$ & $-4.8 \%$ \\
Banking system & $0.5 \%$ & $0.1 \%$ & $0.3 \%$ \\
\hline
\end{tabular}

Table 3. Rate of return of average equity (ROAE)

\begin{tabular}{llll}
\hline Group & $\mathbf{9 / 3 0 / 2 0 1 0}$ & $\mathbf{9 / 3 0 / 2 0 1 1}$ & $\mathbf{3 0 . 0 9 . 2 0 1 2 *}$ \\
\hline Large banks & $11.1 \%$ & $9.3 \%$ & $7.7 \%$ \\
Medium-size banks & $-4.2 \%$ & $-14.5 \%$ & $1.5 \%$ \\
Small-size banks & $-6.1 \%$ & $-8.7 \%$ & $-23.9 \%$ \\
Banking system & $4.0 \%$ & $1.0 \%$ & $2.3 \%$ \\
\hline
\end{tabular}

* Quarterly indicators are reduced on an annual basis.

Source: NBRM - according data from individual banks.

As shown in Tables 2 and 3, the large banks have the largest share in the financial results of the complete banking sector, though their profitability is lower compared to the previous period. But, in September 2012, it is notable that the medium-size banks raised their profits compared to the same period the previous considered years (September 2010, 2011) and the small-size banks have losses and their profitability and it is at the lowest level compared to the other two groups of banks (NBRM, 2011).

Reduced lending activity, reduced operational efficiency, low market share, increase in non-performing loans, the higher reservations amount of bad loans are among the reasons for the lowered profitability of small-sized banks. This tends to support our previous suggestion for mergers or undertaking of smaller banks.

Table 4. Net interest rate/operational costs

\begin{tabular}{lll}
\hline Group & $\mathbf{9 / 3 0 / 2 0 1 1}$ & $\mathbf{3 0 . 0 9 . 2 0 1 2}$ \\
\hline Large banks & 103.9 & 131.1 \\
Medium-size banks & 72.6 & 85.4 \\
Small-size banks & 35.8 & 62.8 \\
Banking system & 88.4 & 93.7 \\
\hline
\end{tabular}

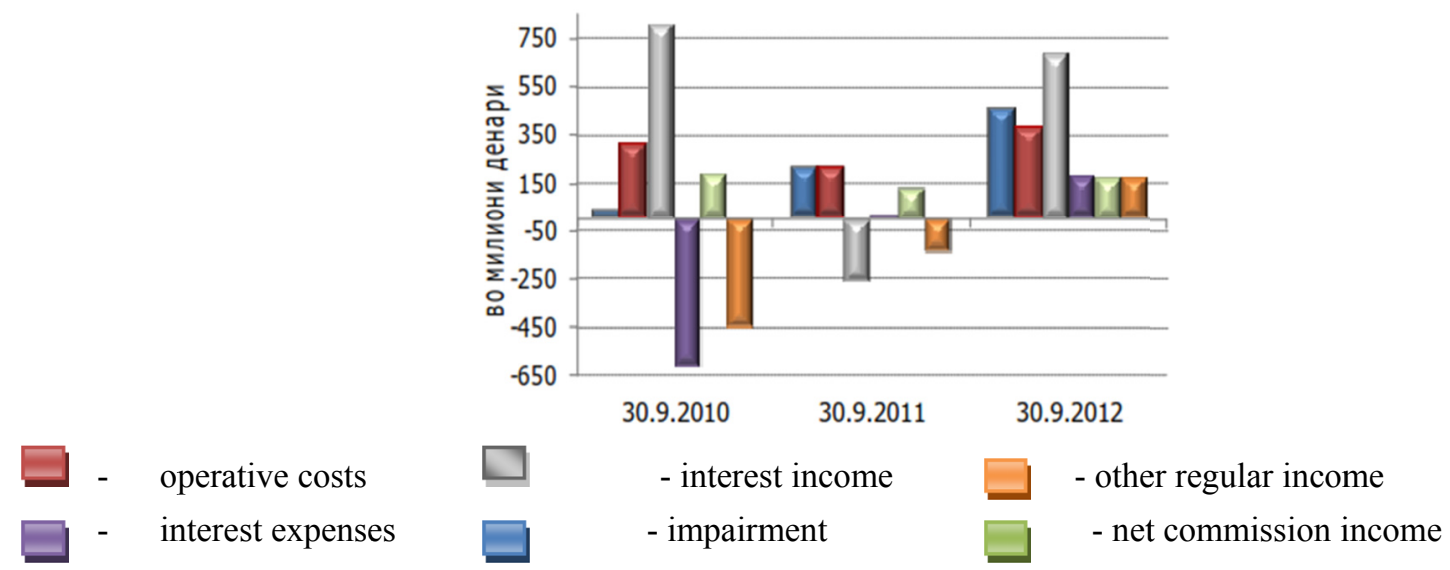

Figure 2. Absolute increase/decrease of the major revenue and expenditure compared to the same period last year Source: NBRM (2012): Report on banking system of the Republic of Macedonia in the third quarter of 2012, p.60

In Table 4 are presented interest income and operative costs observed by groups of banks and for the entire banking system of the Republic of Macedonia. From the data it can be concluded that there is a trend of increased coverage 
of the operative costs with interest income. However, despite this trend, the amount of the operative costs is relatively high. On 09.30.2012, this amount was about 200 million denars higher than the same period last year (Figure 2).

An important component of bank operating expenses is the interest payments that it most make on its liabilities, particular on its deposit. (Mishkin, 2007) The banks explain increased operative costs as a result of $11.3 \%$ annual increase of deposit insurance premiums that in fact corresponds to the annual growth of bank deposits. Increased operative costs are one of the factors for decreased profitability of the total banking system.

\subsection{International Comparative Analysis of the Macedonian Banking Sector}

In order to get a better perspective on the level of profitability of the Macedonian banking sector, it is necessary to make a comparison to the profitability of other banking sectors in some of the countries in the region. (Note 3 ) The analysis included more countries in the region: Bosnia and Herzegovina, Serbia, Bulgaria, Romania, Czech Republic, Hungary, Poland, Slovenia and Croatia.

We compare three key profitability indicators: ROA, ROE and non-performing loans.

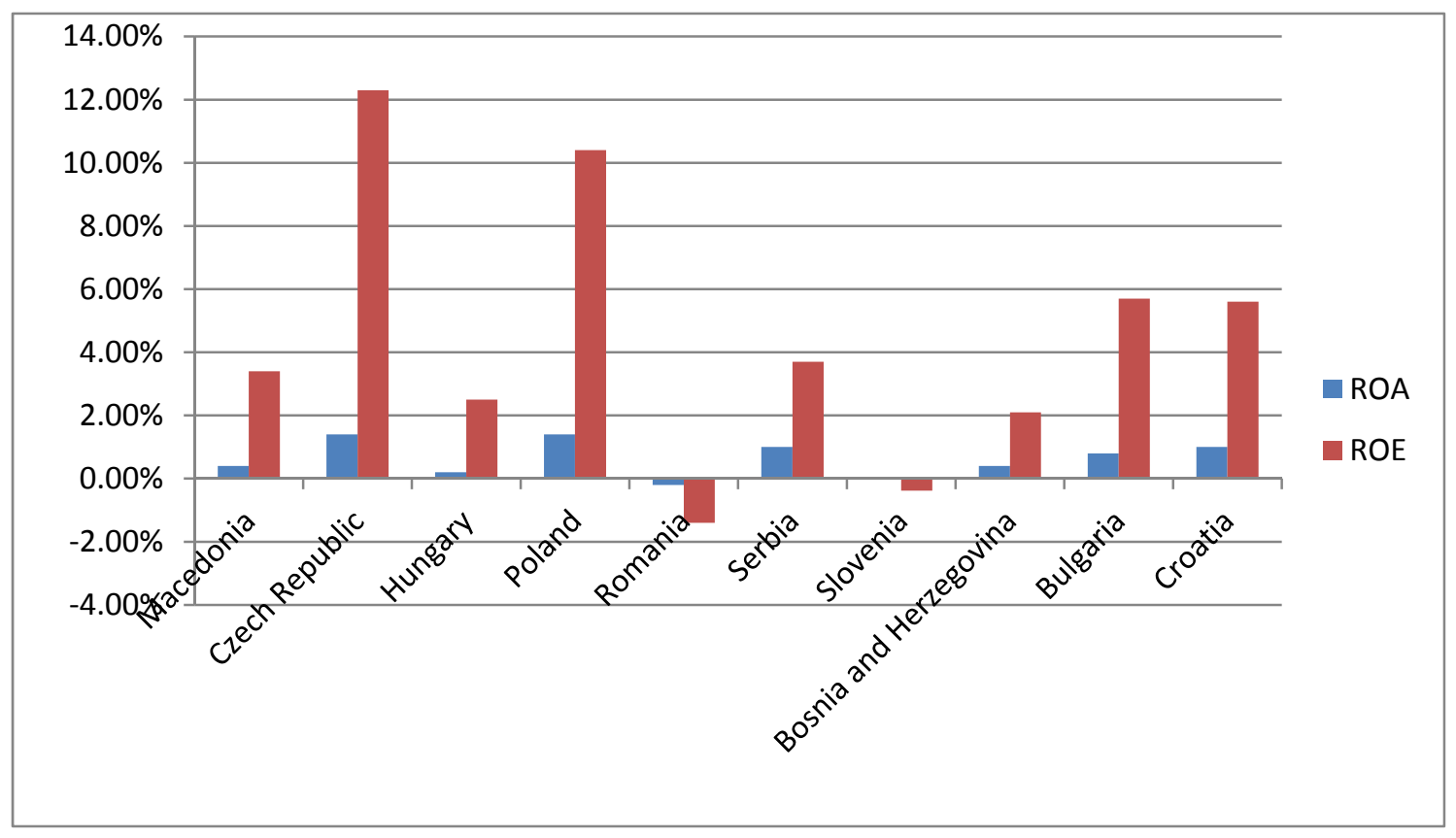

Figure 3. ROA and ROE in certain countries

Sources: UniCredit CEE Strategic Analysis (2012): CEE Banking Outlook.

NBRM (2012): Report on Banking System of Republic of Macedonia in 2011.

The comparison with the mentioned countries showed that ROA and ROE of the Macedonian banking system are in the middle of the list of analyzed countries (behind Serbia, Bulgaria, Czech Republic, Poland and Croatia), but still they are below the determined standards (Figure 3).

Along with the previously mentioned indicators, in order to evaluate the profitability of the banking sector, the percentage of the non-performing loans that the banks have in their portfolios can serve, too. A negative change in this indicator can significantly affect the profitability of the banks. Increased bad loans means that banks allocate higher provisions for risky loans - higher costs which, particularly, has a negative impact on the financial results of smaller banks. 


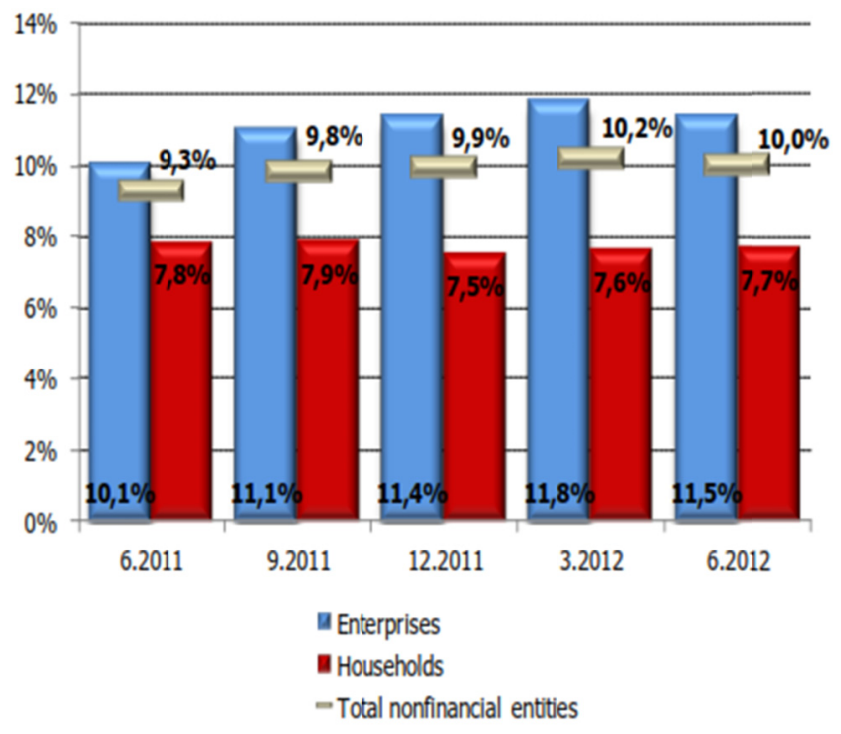

Figure 4. Rate of nonperforming loans, by sector

Source: NBRM (2012). Report on Banking System of Republic of Macedonia in the second quarter of 2012. Skopje, p. 19.

The percentage of the non-performing loans is continually going up (except for March 2012) and the biggest contribution to the growth rate actually has the non-performing loans given to the companies (Figure 4). The companies cannot repay the loans due to the recession and the long period of illiquidity of the Macedonian economy. Reduced liquidity suggests that firm's investments are less profitable. The percentages of the non-performing loans in Macedonia and in several other countries in the region are presented in Table 5.

Table 5. Nonperforming loans (in \%) by countries

\begin{tabular}{lll}
\hline Countries & Nonperforming Loans (in \%) & Date \\
\hline Albania & $14.4 \%$ & 2011 \\
Macedonia & $\mathbf{9 . 1}$ & $\mathbf{2 0 1 1}$ \\
B\&H & $11.7 \%$ & 2011 \\
Croatia & $11.5 \%$ & 2011 \\
Slovenia & 3.7 & 2010 \\
Montenegro & $25 \%$ & 2011 \\
Bulgaria & $13.5 \%$ & 2011 \\
Romania & $13.4 \%$ & 2011 \\
Serbia & $18.6 \%$ & 2011 \\
Czech Republic & $5.6 \%$ & 2011 \\
Hungary & $10.4 \%$ & 2011 \\
Poland & $8.4 \%$ & 2011 \\
\hline
\end{tabular}

Source: http://data.worldbank.org/indicator/FB.AST.NPER.ZS

As shown in Table 5, the percentage of the nonperforming loans in Macedonia, which is $9.1 \%$, is no such a problem if we compare the percentages of Albania (14.4\%), of Croatia (11.5\%), of Montenegro $(25 \%)$ and of Bulgaria (13.5\%). On the other hand, Slovenia has only 3.7\% and Czech Republic has 5.6\% of non-performing loans and it is a good indicator that much more can be done to lower the Macedonian percentage of these loans-that will eventually lead to enhancement of the profitability of the banks. There are a lot of reasons for the existence of these non-performing loans, and some of them are as follows:

- Banks do not have real information about the companies' possibilities of development and how capable the certain business is to generate profit. The banks do not have a solid basis to evaluate how capable they are to return the loans they take; 
- Absence of adequate credit risk management policy;

- Lame capacity of the human resources for a proper revision of the credit risks and absence of adequate training in the field

Popovska, suggests that in order to lower the percentage of the non-performing loans "it is necessary to establish rating agencies, more efficient exchange of credit information within the banking system, to have efficient policy and procedures concerned with the risk management and to have a prudent supervision". (Popovska, 2008)

\section{Basel III Accord and Bank's Profitability}

The appearance of a large number of financial crises, and particular the development and transmission of the global financial crisis of 2007/08, imposes the need for taking appropriate corrective actions in the way of functioning of the international financial system.

In that direction, the Basel Committee on Banking Supervision continuously monitor the changes that occur on international financial market, such as: global financial crisis, new banking products and services, necessity for finding new ways for identifying and managing the banking risks. Therefore, Committee in 2010 introduced new Basel 3 standards in order to strengthen regulatory framework and to increase stability and resilience of the financial sector. (BIS, 2013) The most significant changes that should be made concerning:

- Increasing the required level of capital for covering the risks undertaken by banks, with own capital (share capital - ordinary shares, reserves and retained earnings). Capital adequacy ratio is a measure of the amount of a bank's capital expressed as a percentage of its risk weighted credit exposures. This indicator measures how resistant is the banking system on losses. (RBNZ, 2007)

- Total capital required rose to $8 \%-10.5 \%$.

- New Liquidity Coverage Ratio (LCR) which increases the level of high quality (cash or assets) assets that can be converted into cash at little or no loss of value in private markets to meet its liquidity needs in 30-day period. (BIS, 2012). This standard will reduce the bank run, improve the financial sector stability. Reliance on more liquid assets will have a negative impact on bank's profitability.

Also, there is one more liquidity standard - Net Stable Funding Ratio (NSFR) which should provide better management of medium and long-term financial performance of the banks. This ratio should encourage banks to rely on more stable source of funding (ex.deposits) and increase the competitiveness among banks.

After the Group of Governors and Heads of Supervision of the Basel Committee reached agreement on new Basel capital and liquidity reform package, NBRM prepare information for introduction of Basel 3 standards. The information contains an analysis of the increasing the level of capital required to cover the risks, the introduction of international liquidity standard, and timeframe of their implementation and application. Information also contains an analysis for evaluating the required capital level for coverage the risks in our banking system. (NBRM, 2010)

The analysis confirms that the Macedonian banks fulfill the new capital requirement rates. The capital adequacy ratio is well above the new prescribed rate of $10.5 \%$ and accounted - $17 \%$.

In order to ensure that the Macedonian banks operate according with generally accepted international standards, NBRM adopted a new decision on the methodology for determining the capital adequacy. With this decision change are made in the way the bank defined its own capital and are part of the activities for the application of capital standards defined by the changes in the new Basel Capital Accord. 
Table 6. Capital adequacy ratio (CAR) in 2011

\begin{tabular}{ll}
\hline Country & CAR \\
\hline Macedonia & $17 \%$ \\
Czech Republic & $16 \%$ \\
Hungary & $12 \%$ \\
Poland & $13.60 \%$ \\
Romania & $13 \%$ \\
Slovenia & $11.9 \%$ \\
Bosnia and Herzegovina & 16 \\
Bulgaria & $17.80 \%$ \\
Croatia & $19 \%$ \\
\hline
\end{tabular}

Source: UniCredit CEE Strategic Analysis (2012): CEE Banking Outlook.

Research has shown that the ratio of capital adequacy in the Macedonian banking system of $17 \%$ is among the highest compared to the considered countries. Although, the high CAR promotes stability of the banking system, it may serve to explain the low level of ROE in the banking system of the Republic of Macedonia (Table 6).

Since the main goal of this research is to show the level of profitability of the Macedonian banking system, in this context, we should mention that there will be an increase in bank costs as a result of the introduction of the New Basel Accord.

Thomas W. Killian (2010), says that higher common equity requirements of Basel III (from $2 \%$ to $4.5 \%$ ) could be expected to reduce bank profitability as expressed by return on common equity, put pressure on earnings per share and lower growth potential.

In particular, the introduction of new international standards will increase the cost of funding, need for reorganization and will reduce the profitability of the Macedonian banking system.

In this context it is important to mention that the necessary increase in the required capital may be an issue for small-sized banks. These banks could raise the capital through their enlargement. We had a last example of such consolidation of the banking capital in Macedonia in 2012, when Ziraat Bank AD merged to HalkBank. The process of bank consolidation is supported by NBRM and is expected to continue in the future in order to improve profitability, competitiveness in the banking system and improve the quality of the banking services.

According to bank experts the Macedonian banks continually cooperate with the NBRM in the field of implementation of the new Basel Accord. To what measure the introduction of these standards will affect the profitability of the Macedonian banking sector no one can be sure. It is well known that Basel III standards will be phased in gradually by 2019 that goes in favor to banks.

\section{Conclusion}

As a result of the research done for this thesis we can accept the basic hypothesis and we can make a list of several points as a conclusion, and they are as follows:

1) The research on the profitability of the Macedonian banking sector showed that the small-sized banks have a major role in decreased profitability of the entire sector.

2) It is necessary to lower the number of banks existing in Macedonia through the processes of merging, overtaking of the smaller banks by the big ones, in order to strengthen the competition in the banking sector.

3) Bank consolidation will have the following benefits for smaller banks:

- Increased market share

- Expansion of business activities

- Increased type and quality of service for their clients

- Increased competitiveness

- Increased profitability

- Rationalized expenses

- Strengthen the bank capital. 
4) It should be pointed that the introduction of the new Basel standards will influence the level of profitability of banks in Macedonia. Furthermore, this process is expected to be implemented without difficulty in the expected timeframe.

In order to improve the banking sector as a whole, it is also important to undertake some structural reforms of the banking sector, which will be a topic of further discussion in the future.

\section{References}

Center for Economic Analysis. (2005). The efficiency of the Macedonian Banking Sector. CEA Journal of Economics. Skopje.

Center for Financial Training. (2010). Banking Systems, 2nd Edition 2010, South-Western, Cengage Learning.

Croatian Banking Association. (2009). Profitability of banks in Croatia: How to evaluate downfall? Retrieved from http://www.hub.hr/Default.aspx?art=1935\&sec=566

Davcev, L., \& Hourvouliades, N. (2009). Profitability Parameters in the Banking System of Macedonia. Proceedings of International Conference on Applied Economics 2009. pp. 133-141.

Hubbard, G., \& O’Brien, A. (2012). Money, Banking and Financial System. USA: Pearson Education, Inc.

Killian, T. W. (2010). Basel III and Its Implications: A Closer Look. Sandler O’Neill \& Partners.

KPMG. (2011). Basel III: Issues and Implications White Paper, USA. Retrieved from http://www.kpmg.com/mk/en/issuesandinsights/articlespublications/brochures/pages/baseliiiissuesandimpli cationswhitepaper.aspx

Madzova, V. (2011). Introduction of Basel III: Opportunities and Challenges. Yearbook, 3. University "Goce Delcev" - Stip. R.Macedonia. P.73-84.

Mishkin, F. (2007a). The economy of money, banking and financial markets (8th ed.) Pearson Education, Inc., USA.

Mishkin, F. (2012b). The economy of money, banking and financial markets (10th ed.). Pearson Education, Inc., USA.

NBRM. (2006). Law on National Bank of Macedonia. Official Journal of the Republic of Macedonia, 3/02, 51/03, 85/03, 40/04, 61/05, 129/06. Skopje.

NBRM. (2010). Changes of Basel Capital Accord (Introduction of Basel 3) and preliminary estimates of their impact on the capital adequacy of banks in Republic of Macedonia. Skopje.

NBRM. (2012). Report on Banking System of Republic of Macedonia in 2011. Skopje.

NBRM. (2012). Report on Banking System of the Republic of Macedonia in the second quarter of 2012. Skopje.

Petkovski, M. (2009). Financial markets and Institutions. Skopje, Faculty of Economics.

Popovska, K. (2008). Commercial Banking - Success and profitability. Skopje, "Institute of economics" - Skopje.

Qin, X., \& Pastory, D. (2012). Commercial Banks Profitability Position: The Case of Tanzania. International Journal of Business and Management, 7(13). http://dx.doi.org/10.5539/ijbm.v7n13p136.

RBNZ. (2007). Capital adequacy ratios for banks - simplified explanation and example of calculation. New Zealand.

UniCredit CEE Strategic Analysis. (2012). CEE Banking Outlook.

Notes

Note 1. This is the situation in the Macedonian banking sector in 30.09.2011.

Note 2. $1 \mathrm{CAD}=49 \mathrm{MKD}$.

Note 3. 2011 is last year for which exists comparable data.

Note 4. http://data.worldbank.org/indicator/FB.AST.NPER.ZS

Note 5. http://www.bis.org/press/p130106a.pdf

Note 6. www.bis.org. Bank of international settlement. 